\title{
Clustering and Synchronization in Spin Combustion
}

ISSN: 2578-0255

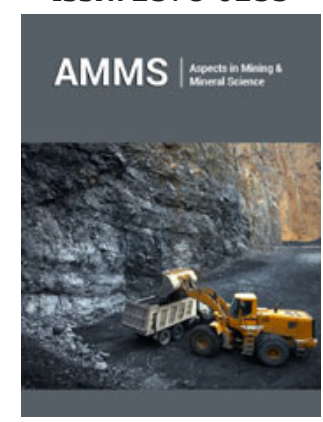

*Corresponding author: Igor A Filimonov, Merzhanov Institute of Structural Macrokinetics and Materials Science RAS, Chernogolovka Moscow Region 142432, Russia

Submission: 崩 February 22, 2021

Published: 枈 March 01, 2021

Volume 6 - Issue 2

How to cite this article: Igor A Filimonov. Clustering and Synchronization in Spin Combustion. Aspects Min Miner Sci. 6(2). AMMS. 000635. 2021.

DOI: 10.31031/AMMS.2021.06.000635

Copyright@ Igor A Filimonov, This article is distributed under the terms of the Creative Commons Attribution 4.0 International License, which permits unrestricted use and redistribution provided that the original author and source are credited.

\section{Igor A Filimonov*}

Merzhanov Institute of Structural Macrokinetics and Materials Science RAS, Russia

\section{Opinion}

The scientific community interest to phenomena of synchronization in wildlife is associated, first of all, with a desire to describe the functioning of living cells. Nevertheless, it is clear that the number of objects of unanimated nature significantly exceeds the number of living organisms. Moreover, each living organism or a cell is built from unanimated elements of the periodic table. Therefore, each manifestation of synchronization in non-living systems is more exciting and interesting than the conventional synchronization inherent to living cells or viruses, both in terms of the emergence of the terrestrial life on and in terms of the greatest coverage of natural phenomena and processes (Figure 1-3). Spin combustion has been studied and detected extensively in different systems. From the gas- solid systems similar to [1] up to termites [2,3]. Both experimental [1-3] and numerical data [4-6,7] concerning this phenomenon have been obtained up today. Nevertheless, both the volumes of these data were analyzed separately in fact. Therefore, some important peculiarities of spin combustion have been actually lost and need to be pointed out especially now. I am only going to remind again results [1] to a reader, and to conduct here their joint analysis with calculations [4-7] in terms of modern achievements of the theory of complex systems [8]. The analysis allows me to argue that spin combustion itself behaves like complex systems. In particular, when spin combustion is initiated, the clustering effect which is schematically illustrated in (Figure 1). happens as a rule already at the earliest stage of spin ignition (see also data [9]). clustering at first not seen in an early work [10], was revealed later in 3-dimensional modeling [11].

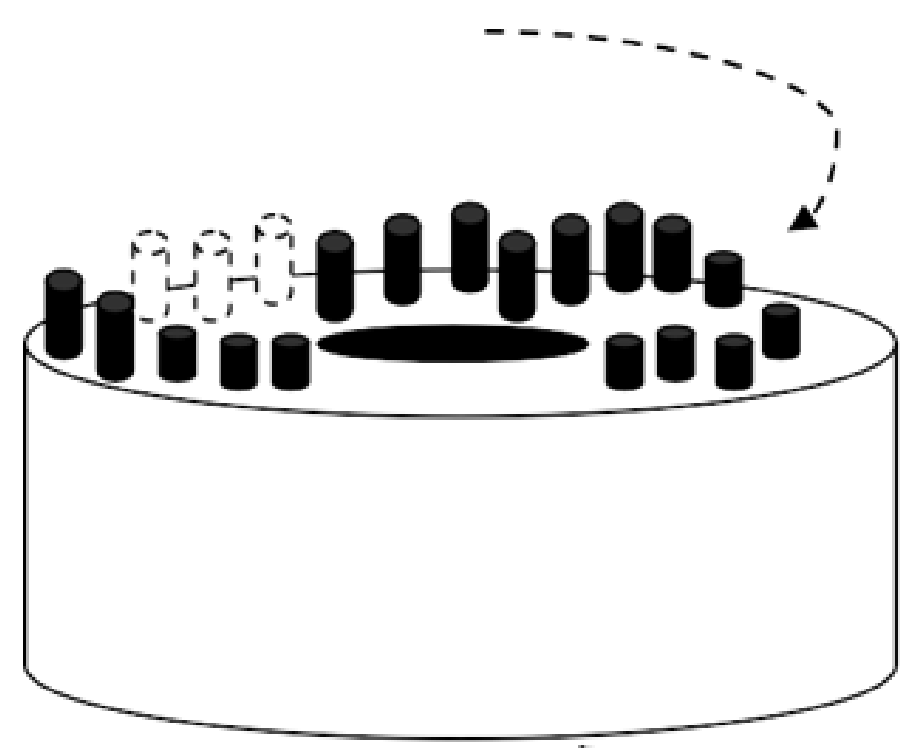

Figure 1: Single-headed spin combustion ignition. Side view of the recalculated results [1] at $0<\mathrm{t}<\approx$ ta (disk-shaped sample) schematically. 


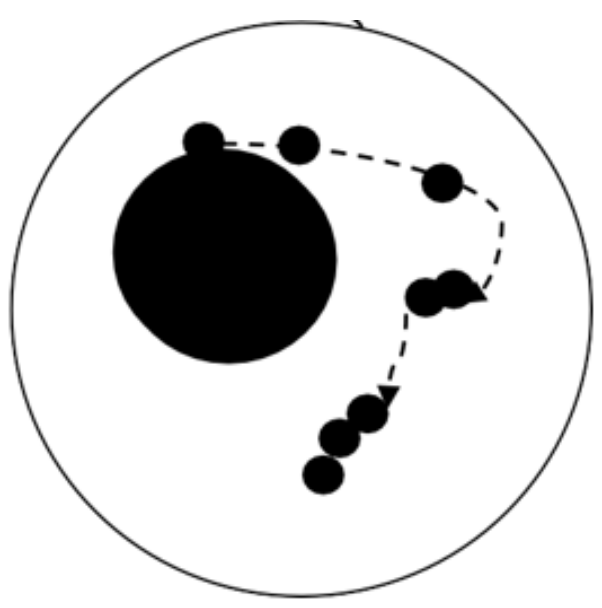

Figure 2: Clustering of a single-headed spin into double-headed or triple-headed spin combustion modes consistently at $\mathrm{t}=\mathrm{tb} \approx>1.29$ ta. Top view of the recalculated results [1] schematically.

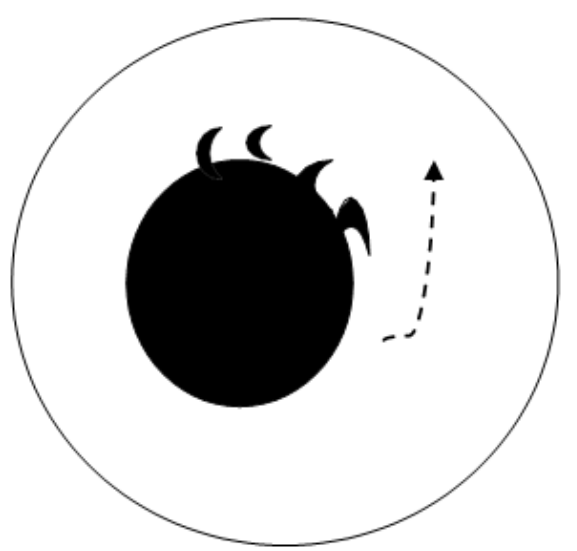

Figure 3: Formation of a saw-tooth structure, STS, (was observed numerically only [7]) Top view of STS schematically at $\mathrm{t}=\mathrm{t}_{\mathrm{c}}>\approx 2.58 \mathrm{t}_{\mathrm{a}}$.

\section{Conclusion}

One may conclude that spin combustion may be attributed to complex systems.

\section{Acknowledgment}

This work was carried out in the framework of governmental program for ISMAN (topic no. 44.1).

\section{References}

1. Vadchenko SG, Filimonov IA (1999) Wave combustion modes of hafnium in nitrogen. Comb Explos \& Shock Waves 35(2): 155-161.

2. Strunina AG, Dvoryankin AV (1981) Effect of heat factors on regularities of the unstable combustion of termite systems. Dokl Akad Nauk SSSR 260(5): 1185-1188.

3. Dvoryankin AV, Strunina AG, Merzhanov AG (1982) Trends in the spin combustion of termites. Combustion, Explosion and Shock Waves 18: 134-139.

4. Novozhilov BV (1993) The theory of surface spin combustion. Pure \& Appl Chem 65(2): 309-316.
5. Novozhilov BV (1993) Quasistationary theory of spiral combustion regime. Internat J SHS 2(3): 207-213.

6. Filimonov IA, Kidin NI, Mukasyan AS (2000) The effect of infiltration and reactant gas pressure on spin combustion in a gas-solid system. Proc of the Combustion Institute 28(1): 1421-1429.

7. Markov AA, Filimonov IA (2021) Papers in print.

8. Manrubia SC, Mikhailov AS, Zanette DH (2004) Emergence of dynamical order: synchronization phenomena in complex systems. World Scientific Publishing Co Pt Ltd p. 359.

9. Rubtsov NM, Seplyarskii BS, Alymov MI (2021) Initiation and flame propagation in combustion of gases and pyrophoric metal nanostructures, springer. Fluid Mechanics and its Applications (123).

10. Ivleva TP, Merzhanov AG, Shkadinskii KG (1980) Principles of the spin mode of Combustion front propagation. Combustion and Explosion Physics 16(2): 3-10.

11. Ivleva TP, Merganov AG, (2000) Three-dimensional spinning waves of gasless combustion. Dokl Akad Nauk 371(6): 753-758.

For possible submissions Click below: 